\footnotetext{
A AndragošKe Studije, ISSN 0354-54I 5, BROJ I, JUN 202 I, STR. 57-74

3 (c) InSTITUT ZA PEDAGOGIJU I ANDRAGOGIJU; ORIGINALNI NAUČNI RAD

UDK 374.7:37.014-054.73

DOI: I0.5937/ANDSTUD2101057K
}

Zoe Karanikola ${ }^{1}$, Nektaria Palaiologou ${ }^{2}$

Hellenic Open University, Greece

\title{
Refugees and Adult Education: A Thematic Analysis on UNESCO's Latest Recommendations
}

\begin{abstract}
Contemporary societies are called to face complex challenges, deriving from globalization, the rapid technological evolutions, the intense demographic changes, and the social exclusion. These challenges are part of UNESCO's global mandate, as reflected in the Education 2030 Framework for Action for the implementation of Sustainable Development Goals, and have more impact on migrations and refugees. UNESCO's Global Report on Adult Learning and Education comes to play a crucial role in achieving the fourth goal of the Agenda, that of education and lifelong education. The present research, through the qualitative analysis of the text of UNESCO (GRALE 4, 2019), aims at pointing out the basic dimensions of adult refugees' education and how it can be applied. Through the analysis of the text certain thematic networks emerge, related with the participation percentages of adult refugees' participation, mapping out of policies, whose particular characteristic is the investment in lifelong learning, transmission of good practices and their evaluation.
\end{abstract}

Key words: Adult education, participation, refugees, policies, practices.

\section{Theoretical Underpinning}

\section{Adult education and refugees}

Europe is facing an unprecedented migrant crisis, since hundreds of thousands of refugees and migrants continue to make their way across the Mediterranean to Europe with hopes of a better life. It is estimated that more than 65 million people today are asylum seekers, internally displaced persons or refugees, whereas

${ }^{1}$ Zoe Karanikola, PhD is a Tutor at the Hellenic Open University, School of Education, Greece, (zoe karanikola.zoi@ac.eap.gr).

2 Nektaria Palaiologou, PhD is an Assistant Professor at the Hellenic Open University, School of Education, Greece, (palaiologou.nektaria@ac.eap.gr). 
the average length of time a refugee spends in exile is about 20 years (UNESCO, 2017). According to some recent UNHCR data (2021a), in March 20216000 refugees and migrants arrived in Europe via the Mediterranean and Canary Islands routes, a $40 \%$ increase compared to March 2020. In addition, in the first three months of 2021, some 4600 refugees and migrants crossed the sea from Libya to Europe, a 53\% increase compared to the same period in 2020 (UNHCR, 2021b).

More and more the international discourse expresses concerns about the limited enjoyment of rights by refugees and the violations of their rights to life, liberty and security. Attention is turned to the disturbing tendency to close doors to refugees, to violations of the minimum rights of asylum-seekers, and to the demonstration of phenomena such as intolerance, racism, xenophobia, aggression, which affect their lives in a negative way (OHCHR, 1993), and lead them to social exclusion. Social exclusion is defined as a process whereby individuals or groups are not able to participate fully in society as a result of unemployment, low skills level, ill health, language difficulties or other factors (Banulescu-Bogdan, 2020, pp. 4-5). Specifically, "lack of language skills or limited language skills is a powerful barrier to integration and labour-market success" (CEDEFOP, 2011, p. 12).

\section{Refugees' education and challenges}

Regarding refugees' education, there are many challenges related to access, quality and relevance. The difficulties that refugees frequently face in transferring skills, competences and qualifications to new contexts is the subject of a growing body of scholarship (Morrice, Shan, \& Sprung, 2018, p. 130). Specifically, there is significant heterogeneity, given that "there are at least two distinct groups, highly skilled, for whom international mobility is part of their career, and low-skilled" (CEDEFOP, 2011, p. 7) who face much difficulty in finding a job. In addition, it is argued that their education faces problems such as interrupted education, significant learning gaps, inappropriate skills, and confusing application procedures, whereas less than $1 \%$ of refugee youth are able to participate in higher education (UNHCR, 2016). The consequences of not having access are disturbing, since refugees are condemned to passivity, stress, frustration, violence (World Education News and Reviews, 2015).

In addition, national governments have to provide trained teachers and learning material for newcomers who do not speak the language, lack identification documents or academic transcripts needed to transfer to a new institution and it is difficult to evaluate their educational background (UNHCR, 2016). 
There is also a growing critique of the way that adult education programs focus on the needs of refugees, while ignoring the learning that might be helpful to the host society (Shan, 2015). For instance, in a study of the curriculum orientation of Language Instructions for Newcomers to Canada, Cervatiuc and Ricento (2012, as cited in Shan, 2015, p. 3) found that trainers may conveniently take a prescriptive approach to teaching the dominant culture to newcomers, rendering their irrelevant cultures, epistemological views and life experiences.

On the contrary, successful training programmes are those that "activate a crucial amount of social capital in the form of unions, employer federations and communities" (CEDEFOP, 2011, p. 15). Consequently, refugees can "tap into their rich social capital for job contacts" (CEDEFOP, 2011, p. 15) and opportunities, may "benefit from networking contacts with native workers that may meet during their course of study" (CEDEFOP, 2011, p. 15).

In addition, available courses are usually too far away from where refuges live and occasionally they are incompatible with work and family responsibilities. Newcomers may not feel comfortable attending them, especially women who face cultural pressure not to participate in public activities. In addition, they are "at a disadvantage given that they have less social capital than natives, fewer contacts ... lack of knowledge and information" (CEDEFOP, 2011, p. 10). Widely speaking, the barriers that refugees are facing could be categorized in structural/policy barriers (asylum, distribution, housing policies), time and resource barriers (lack of time, skills, institutional knowledge), life-cycle barriers (individual's age and family status), cultural barriers (e.g. women from Muslim communities may be discouraged from participating in mixed-gender training programs), and socioemotional barriers (mental health challenges and traumas) (Banulescu-Bogdan, 2020).

\section{Practices and policies promoting refugees' education}

In such a context, over the last years there has been a vivid interest in adult education regarding refugees, given that it provides a substantial contribution to personal development, social inclusion and integration, an opportunity to promote the values of tolerance, democracy and solidarity. In addition, it can introduce the refugee community to the host population, whereas formal and informal educational activities can reduce tensions between communities, and also eliminate inefficiencies in the labour market (Halachev, 2015).

The European Commission facilitates the exchange of good practices among Member States, promotes networking among policymakers, and its agenda focuses on topics such as: language assessment and integration of unac- 
companied minors through education, reception of newly arrived refugees and migrants, and assessment of previous schooling, recognition of refugees' qualifications, intercultural dialogue as a tool to address migration, refugees and asylum seekers in educational contexts, linguistic and cultural diversity, integration policies (European Commission, 2017).

Towards this direction, the Global Framework for Refugee Education (UNHCR, 2019) aims to create the conditions of global support for the education of refugees and host communities. Its basic axes are to increase funding and national capacity, to strengthen programming and planning based on analysis of barriers, assets and opportunities for including refugees in host-community schools and engaging refugee and host communities to build trust and cohesion, to support and train teachers by investing in appropriate programmes and national policies, to increase investment in existing national data systems, to strengthen partnership and coordination between education ministries, development and humanitarian partners, to engage and account to refugees and host communities, and to ensure meaningful consultation and participation of both refugees and host communities in decision making and initiatives.

In addition, many refugee-receiving countries revise their formal integration programs in order to reach their vulnerable groups. In parallel, there has been a surge in public activism, with new start-ups and private initiatives being launched in an effort to fill the perceived gaps in government programming (e.g. Germany's Strong Work Program).

According to Heinemann's recent study (2018), newcomers to Austria and Germany are obliged to learn German, as both of the nation states define themselves as monolingual-although millions of citizens speak more than one language. According to the researcher, "the demand to learn the national language by refugees is promoted by the shaky promise that it is an entrance ticket to the labour market and also a sine qua non to be respected by German and Austrian citizens". The first results of this study highlight the reproduction of mainstream norms and the production of three different interwoven subject types who either adjust or not to host country's societal norms and new market conditions, i.e. "one who responds appropriately to the needs of a national neoliberal labour market; another one who agrees to norms and rules without the power to fully politically participate and a third who forms the pleasing constitutive outside of the national body" (p. 177).

Furthermore, such programs contribute to refugees' integration by aiming at their economic empowerment, volunteering, and building social ties. Economic empowerment programs fall into categories such as cooking (e.g. ethnic 
food becomes an important gateway into work), crafts, childcare and gardening, (Banulescu-Bogdan, 2020).

Finally, regarding practices implemented, they are monitored and systemized since the situation is described as an experiment with a "trial and error" method. Such approaches are valuable and often accompanied by comparing different national approaches to migration (Käpplinger, 2018).

\section{Methodology of Research}

\section{Research objective research questions}

This study comes to investigate the basic dimensions of adult education as far as refugees are concerned through the content analysis of the text of UNESCO, GRALE IV (2019). The research questions that arise for this particular study are the following:

- How often do refugees participate in adult education?

- Are there any obstacles and barriers in their participation?

- What kind of policies and practices are promoted regarding their participation?

\section{Presentation of research material and methodological tool}

The text of UNESCO "4th Global Report on Adult Learning and Education" (GRALE 4, 2019) is based on the framework of the United Nations' 2030 Agenda for Sustainable Development (UN, 2015). "Giving everyone a fair chance" is its main idea (GRALE 4, 2019, p. 13), meaning that everyone should have access to the benefits of adult education. In addition, this report provides an overview of the latest data and evidence on Adult education, whereas highlights good practices. A total of 159 countries (157 Member States and two Associate Member States) responded to the survey of GRALE 4 . The response rates were $72 \%$ in sub-Saharan Africa, 90\% in the Arab States, 67\% in Central Asia, 78\% in East Asia and the Pacific, 89\% in South and West Asia, 95\% in Central and Eastern Europe, $81 \%$ in North America and Western Europe, 79\% in Latin America and the Caribbean, $90 \%$ in the Arab States (GRALE 4, p. 28).

Regarding the methodology followed, the qualitative analysis was applied and more specifically the methodological tool of thematic analysis was used. This 
tool is distinguished for its clarity and flexibility, whereas its main objective is the methodical and systematic analysis of the research material, and the extensive exploration both of the surface and the deeper structures of the text (Braun \& Clarke, 2012; Vaismoradi \& Snelgrove, 2019). The development of qualitative methods is a result of the acceptance of the explanatory model that shows the general picture and the prevailing trends, while at the same time it is a form of coding of qualitative data (Clarke, Braun, \& Hayfield, 2015).

The thematic analysis includes six steps: familiarizing with data (reading, re-reading, and taking notes), generation of initial codes (coding interesting feature across the entire data set), searching for themes (collecting codes into potential themes, gathering all data relevant to each potential theme), reviewing themes (generate a thematic map of the analysis and check the themes relevance in relation to coded extracts and entire data), defining and naming themes (ongoing analysis to refine the specifics of each theme, and the overall story of the analysis tells, generating clear definitions and names for each theme), and producing the report (selection of vivid, compelling extract examples, final analysis of selected extracts, relation back of the analysis to the research questions and literature, producing a report of the analysis) (Persson, Törnbom, Sunnerhagen, \& Törnbom, 2017).

Theme development starts after the researcher has defined the object of the study. Analysing data means interconnections between codes and spotting themes appropriate for the available data (Knudsen et al., 2012). According to Attride-Stirling (2001), there are three classes of themes, the basic, the organizing and the global theme. The first refers to the simplest characteristics of the text, in order to achieve a clearer understanding of the text content. All together, they make up the second class of themes and more specifically the organizing theme, which is a middle-order theme. This particular theme contributes to better understanding of a more general theme, which connects enough organizing themes. The third theme (the global theme) arises in this way and it is a super-ordinate which contains the basic idea of the text as a whole (as cited in Panagiotopoulos \& Karanikola, 2017).

In this research the global theme is adult refugee education, and the organizing themes that arise from the analysis of the text are: participation (obstacles and percentages), policies (traits, axes, financing, qualifications and skills), and examples of programs (Figure 1). 


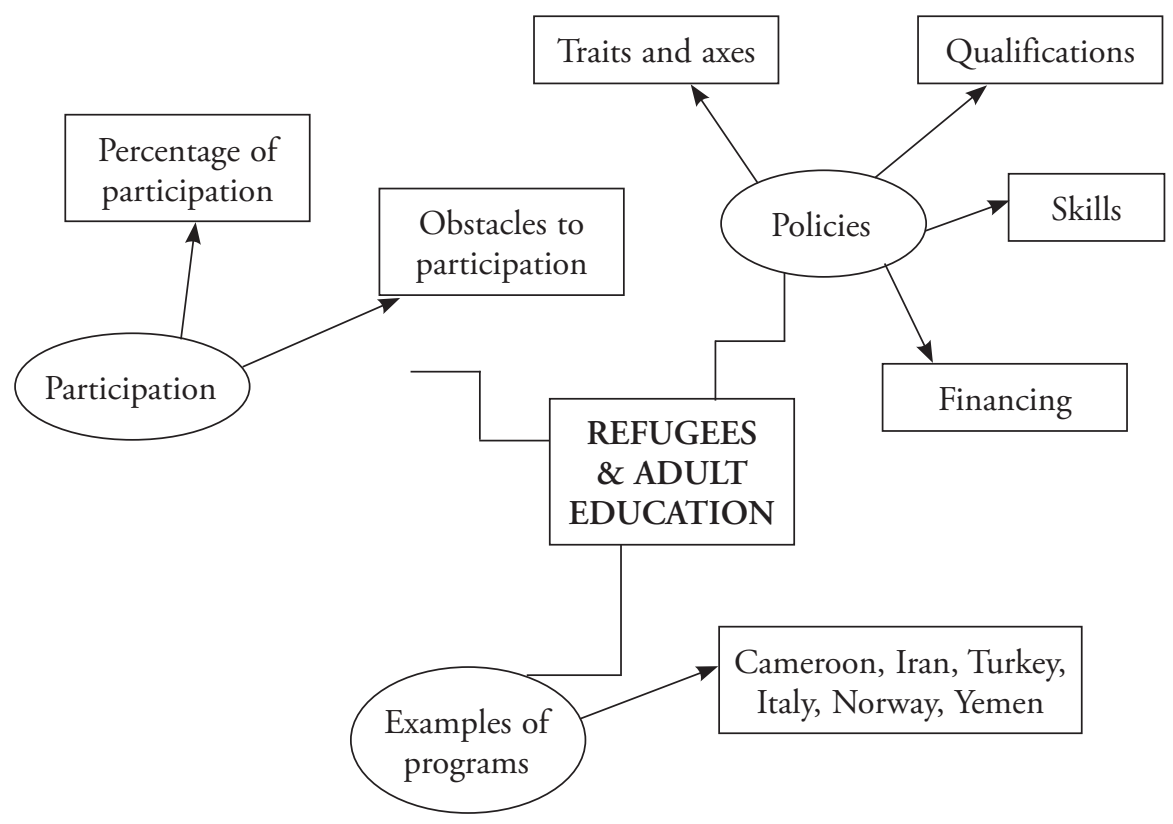

Figure 1. Structure of the thematic network (Source: Karanikola \& Palaiologou, 2020, IPR)

\section{Creation and description of set of themes}

\section{Refugees' participation in adult education}

The first organizing theme refers to the issue of refugees' participation in adult education and learning. It is quite interesting that despite the fact that refugees and migrants are a crucial and important population target for the policies of the International Organizations, there are still "globally, between and within counties, deep and persistent inequalities regarding their participation in adult education" (GRALE 4, 2019, p. 22, p. 57).

Regarding their participation, two main matters are emerging. "The first is that disadvantaged, vulnerable and excluded populations" (GRALE 4, p. 14) (migrants and refugees, women, adults with disabilities, adults disadvantaged due to lack of education and skills, residents of remote or rural areas, residents in urban areas, minority groups - ethnic, linguistic, religious, unemployed adults, older adults) "tend to do by far the worst when it comes to participation in adult education and learning, and the second is that there is insufficient knowledge about 
participation, particularly in low-income countries" (GRALE 4, p. 14). Particularly, "more than a third (37\%) of the countries participating in the research, reported not knowing the adult education participation rates of minority groups, refugees and migrants" (GRALE 4, 2019, p. 14, 20), "27\% reported no change in adult education provision for refugees and migrants, whereas $38 \%$ reported some increase" (GRALE 4, 2019, p. 79). Generally, "of the 159 countries, almost half either did not answer the question regarding refugees' participation or stated that they did not know" (GRALE 4, 2019, p. 135). Consequently, this global survey "does not provide any data on actual participation rates, only whether or not countries have experienced a change in participation among refugees" (GRALE 4, 2019, p. 136).

It is also worth mentioning that in previous Global Reports there were even less elements on participation by refugees. Particularly, GRALE 1 (2009) highlighted the unequal nature of participation within countries (GRALE 4, 2019, p. 74), GRALE 2 (2013), reported that ethnic minorities, refugees and migrants were still excluded from adult education provision, while data were nearly absent from GRALE 3 (2016), where " $62 \%$ of countries reported not having participation rates for ethnic, religious and linguistic minorities and 56\% reported not having participation data for migrants and refugees" (GRALE 4, 2019, p. 74).

\section{Obstacles and barriers preventing refugees}

What are the barriers and obstacles preventing refugees from participating in formal and informal types of adult education and learning? "One major barrier is the lack of literacy and language courses for migrants and refugees, who also face challenges in having their skills and competencies recognized and validated" (GRALE 4, 2019, p. 22). In addition, this population is highly heterogeneous, both across and within the countries, and different groups have different needs. According to the International Labor Organization (ILO) (2018, as cited in GRALE 4, 2019, p. 135), "while the majority of the global migrant population consists of skilled and highly skilled persons, there are also large segments with very low skills, particularly among refugee groups".

\section{Policies supporting refugees' adult education}

"These policies accompanied by legislative measures need to be comprehensive, inclusive, integrated within a lifelong and life-wide learning perspective, based on sector-wide and intersectoral approaches, covering and linking all components of learning and education" (GRALE 4, 2019, p. 33). In addition, according to the 
UNESCO (GRALE 4, 2019, p. 35) relative policies should include five fundamental axes in order to be more effective and equal. Specifically, "adult education is part of the human right to education, a potential means for marginalized groups to achieve equality, an opportunity for learning throughout life regardless of learning objectives, comprehensive provision utilizing various kinds of learning activities, and a long-term approach to achieve intended outcomes".

One basic dimension of the policies is increasing and widening adult participation through a range of tools, such as "focused investment, particularly on the last disadvantaged, interventions in order to raise demand (e.g. stimulating interest through celebrating success stories in festivals and media), reducing the cost of participation, particularly for poorer members of society, financial incentives to reduce cost barriers, non-financial incentives (voucher schemes, paid leave and opportunities for career development), ensuring effective information, advice and guidance for all learners throughout their lives, countrywide strategies to ensure learners have access to ICTs and the skills to fully exploit them" (GRALE 4, 2019, p. 23).

Equally important is the factor of financing adult education. According to the data of GRALE 4 (2019), refugees and migrants tend to be under-represented and not a priority in adult education spending. Specifically, $48 \%$ of the countries stated that this group of adults is "not much" or "somewhat" a priority (p. 58). It is also worth mentioning that " $28 \%$ of counties reported not knowing whether migrants and refugees were a priority for government financing of adult education" (p. 58). As for the "minority groups", the percentage was 32\%.

Last but not least, a basic challenge of policies regarding the participation of refugees and migrants is providing them with appropriate and right skills. Inadequate skills makes it difficult for them to compete for employment. According to ILO (2018, as cited in GRALE 4, 2019), around "60\% of Syrian refugees aged 16 years or older have not completed basic schooling and only $15 \%$ have finished secondary education" (p. 135). In comparison, " $42 \%$ of Jordanians" (same age range) "have a secondary education" (p. 135). Furthermore, Syrian refugees after having lived in camps and being unemployed for a long time have a serious lack in skills. "A survey conducted in one of the largest camps in Jordan revealed that over a half of the women and three-quarters of the men indicated argued that if they were offered the chance to attend skills training programs, they would enrol and then seek a job outside the camp" (UNHCR, 2017 as cited in GRALE 4, 2019, p. 135).

Refugees living in the EU face similar situation to those in Jordan. According to EUROSTAT (2017, as cited in GRALE 4, 2019, p. 135), "the proportion of non-EU-born immigrants aged 25-54 with low education attainment 
is twice as high as for those living in the EU country in which they were born. What is more, the rate of young people (15-29) not employed and not enrolled in education or training is almost twice as high among those born outside the EU compared to the native population".

Towards this direction, the skills challenges facing migrants are highlighted by an OECD study (2018, as cited in GRALE 4, 2019, p. 135). Specifically, "migrants were less proficient in literacy, numeracy and problem-solving than native-born adults, whereas there were many high skilled migrants".

Finally, for adult education and learning a main target is providing vulnerable and disadvantaged groups with "literacy and basic skills, vocational skills and active citizenship skills through liberal, popular and community education" (GRALE 4, p. 27)

\section{Good practices and examples}

According to the analysis of the text, there seems to be many good practices and examples deriving from different countries. To begin with, in Italy (2015), the Provincial Centres for Adult Instruction (CPIAs) were given organizational and didactic autonomy, whereas the groups eligible for enrolment are among others foreigners who want to obtain the primary and secondary school-leaving qualifications, foreigners who want to obtain an upper secondary school-leaving qualification, and foreign adults that wish to enrol in Italian as a second language courses (GRALE 4, 2019).

Secondly, the Ministry of Social Affairs in Lebanon started a national adult post-literacy program in the social service centres in Bourj Hammoud, in an effort to help low-skilled refugees acquire and retain their literacy skills. Simultaneously, they were offered some extra seminars, the topics of which were healthy nutrition and cooking.

In addition, during 2017-2018, INSAN, a nongovernmental organization offered programs to enhance "literacy, computer, English and life skills of displaced Syrians and members of Lebanese society for both genders". These programmes equipped the participants with the right skills in order to "enter the labour market, and to rebuild their societies and communities" (GRALE 4, 2019, p. 136).

Meanwhile in Yemen, the United Nations Refugee Agency established adult education programs for refugees living in Sana'a, the country's largest city (mainly literacy program in particular for women, 96\%). "Students complete the equivalent of six years of primary schooling in three years, and receive a certificate from the Ministry of Education. One of the challenges identified is the reluctance of children to attend literacy classes with adults" (GRALE 4, 2019, p. 137). 
One successful program is offered by the Kirikhan Community Centre in Turkey, a country with one of the world's largest refuge populations. It is sponsored by YUVA, a Turkish non-governmental adult learning organization, and DVV International. Its aim is to bring together Syrian refugees and the local population, to know each other, to communicate and study together. The topics covered by the program are: psycho-social activities, language training, ICT, life skills, hobby-oriented courses, vocational training and awareness about legal rights (GRALE 4, 2019).

Furthermore, "Germany has initiated numerous programs to support the integration of the newly arrived, mainly through the provision of language courses. It is also worth mentioning that they make efforts to harness digital media for the purpose of making learning and information more effective and accessible" (GRALE 4, 2019, p. 137).

"Cameroon reports opened literacy centres in refugee camps in the far north and east of the country, whereas the Islamic Republic of Iran has removed all barriers to delivering formal and non-formal educational services for Afghan refugees. Finally a Norwegian policy paper (2016) aims to prevent exclusion from the labour market" (GRALE 4, 2019, p. 137).

\section{Discussion on the Results}

According to the findings of the qualitative analysis of the text, a basic dimension of refugees' adult education refers to their access and participation. It is worth mentioning that there is insufficient knowledge about participation, particularly in low-income countries. In addition, there are many significant obstacles regarding their participation resulting in low percentages. Lack of literacy and language courses, low and inappropriate skills, without validation and recognition competencies, heterogeneous groups are mentioned as crucial barriers (Kaur, 2011; UNESCO, 2019). Except for them, some researchers also mention lack of childcare, family responsibilities, low income, shift work, affordability, housing problems, lack of information and awareness, gender barriers, concentration problems, selfperception, low self-esteem and expectations, low motivation, interest and confidence, distrust, tiredness (Altinkaya \& Omundsen, 1999; Banulescu-Bogdan, 2020; Benseman, 2014; Watts, White \& Trlin, 2001). In addition, Hayward (2007) refers to the psychological or physical trauma that many refugee learners have in their new countries. Towards this direction Adkins, Sample and Birman (1999) discuss the role of stress. 
Regarding the policies supporting adult education, they should be comprehensive, inclusive, integrated within a lifelong learning perspective. This aspect is also supported by many international organizational official policy recommendations (European Parliament, 2016; GRALE III, 2016; OECD, 2013; UNESCO Institute for Lifelong Learning, 2010, 2016). According to these, adult education policies should be characterized by ecumenism, inclusion and united political approach of all members and they should be an internal part of lifelong learning with frequent evaluation of progress, diagnostic evaluation of national policies not only of the requirements of the job market but also of personal and social needs (Panagiotopoulos, Pertesi \& Karanikola, 2018).

Policies should also focus on developing the right type of skills. Towards this direction, "lifelong strategies should allow those who have left early to reenter education, and those who need it should be able to access higher education and Vocational Education and Training (VET) programmes to acquire update skills that the jobs of tomorrow require" (European Commission, 2020, p. 7). Skills such as reading, writing, numeracy and technology, which benefit adults' lives both socially and economically (Heinemann 2017; Panagiotopoulos \& Karanikola, 2017; UNESCO Institute for Lifelong Learning, 2015).

Regarding financing adult education, it is argued that refugees and migrants are under-represented and not a priority in adult education. However, low investment in adult education is something common in many countries. According to GRALE II (2009), public funding in regard to adult education is disappointing $(2.2 \%)$, since the investment priorities of governments and international organizations are health, building infrastructure and social welfare. This percentage increased gradually, according to GRALE III (2016, p. 48), "since $48 \%$ of the states reported remarkable innovations in funding comparatively with the year 2009". This effort was blocked by the global economic crisis in 20082009 that led the big economic forces of the European Union, the United States and China to "reduce financial resources and as a result adult education competes with other investment priorities" (UNESCO, 2016, p. 45).

Furthermore, collaboration between member-states and the exchange of good practices is also needed in an effective policy. Governmental organizations, research institutions, different organizations of citizens, trade unions and other institutions that promote adult education through programs and activities aid at this attempt. During the transmission of ideas, particular attention should be paid to the conditions and the characteristics of the countries, so that they adopt elements that suit the structures, the methods and the techniques of their education (UNESCO, 2016). 
The exchange of ideas and practices is not only beneficial between states in global level but also between local and regional authorities in national level. The governments in collaboration with the services of the Region extend their policies to reinforce the mechanisms of adult learning and education. Besides, the quality of the educational framework is evaluated according to the transmission of ideas and the transfer of responsibilities especially from the lower levels to the higher levels of education (bottom to up), which promote professional development (UNESCO, 2016).

The evaluation of policy methods from the makers of educational strategy is an integral part of adult education. The educational policy makers (like Ministries, private institutions, local authorities, international and regional organizations) have to modernize their policies according to the economic, political, social, cultural and technological environment. In addition, education key holders have to check and evaluate the application of educational methods and techniques that are developed, so that they are quite flexible with future needs, matters and challenges that emerge in the educational world. In order for something like this to be achievable there should be a single network of operation and distribution of resources that is flexible, rapid and decentralized, ensuring the response to the requirements of the modern world (Schuller \& Watson, 2009).

Adult education constitutes a multidimensional and compound field of policy that interacts with other sectors of policy. The responsibility, however, for adult education is divided in many public services (like education, immigration) and ministries (like the Ministry of Education), but also in various policy levels (national, regional, local). This unclear separation of responsibilities by the bodies and structures of education, the lack of co-ordination and the different approaches of political parties contribute to the fragmentation and the in efficiency of evaluation in the field of adult education (Desjardins, 2017). Through this process not only the benefits but also the deficiencies of policy directions that were followed are depicted and final objective is to reconstruct them in order to achieve higher cost savings.

\section{Concluding Points}

It should be pointed out that this present research is limited to the investigation of a way to develop the dimensions of refugees' adult education, as it appears from the content analysis of the text GRALE 4 (2019). However, certain questions arise in regard to the practical implementation of the methods determined by the international framework. Will the objectives of Agenda 2030 be included 
in the policies of member-states and, if they do, to what extent? Will the policy and implementation of the Agenda 2030 tackle global problems that are the cause of refugee crises? Let's not forget that more than $70 \%$ Syrian refugees are living in poverty, with limited access to basic services, education or job opportunities and few prospects of returning home (UNHCR, 2021c), despite the fact that the goal of the Agenda was to eradicate poverty and hunger, generalize the education at all levels both in developing and developed countries, develop gender equality, health, well-being and prosperity, improve access to new forms of energy, environmental protection and respect for human rights (United Nations General Assembly, 2015).

In addition, while the UNESCO frequently mentions in its official texts the necessity of cohesion, collaboration of policies and exchange of good practices among member-states, why do vulnerable groups of adults (unskilled adults) still remain out of the educational framework (CEDEFOP, 2016).

Consequently, the issue of transition of policy from the official documents to the field of application arises. Nowadays institutions of adult education are called to develop new curricula also addressed to refugee populations, aiming to offer a variety of flexible training programmes, through which refugees could acquire new skills in order to find a work at the labour market. Alternatively, even better, if conditions are met, refugees could start the entrepreneurial discourse (Fenwick, 2001). Reality shows that rather than offering only educational programmes exclusively through formal education it would be more practical to design vocational training programmes through which newcomers populations could acquire new skills and competences.

\section{References}

Adxins, M. A., Sample, B., \& Birman, D. (1999). Mental health and the adult refugee: The role of the ESL teacher. Washington, DC: National Center for ESL Literacy Education.

Altinkaya, J., \& Omundsen, H. (1999). Birds in a gilded cage': resettlement prospects for adult refugees in New Zealand. Social Policy Journal of New Zealand, 13, 31-42.

Attride -Stirling, J. (2001). Thematic Networks: An Analytic Tool for Qualitative Research. Qualitative Research Copyright, I (3), 385-405.

Banulescu-Bogdan, N. (2020). Beyond work. Reducing social isolation for refuge women and other marginalized newcomers. Migration Policy Institute. Retrieved from https://www.migrationpolicy.org/

Benseman, J. (2014). Adult Refugee Learners with Limited Literacy: Needs and Effective Responses. Refuge: Canada's Journal on Refugees, 30(1), 93-103. 
Braun, V., \& Clarke, V. (2012). Thematic analysis. In H. Cooper, P. M. Camic, D. L. Long, A. T. Panter, D. Rindskopf, \& K. J. Sher (Eds). APA handbook of research methods in psychology, 2: Research designs: Quantitative, qualitative, neuropsychological, and biological (pp. 57-71). Washington, DC: American Psychological Association.

CEDEFOP. European CoMmission. (2011). Employment-related mobility and migration, and vocational education and training. Luxemburg: Publications Office of the European Union.

CEDEFOP. European Commission. (2016). Update to the European inventory on validation of non-formal and informal learning: Synthesis Report. Luxemburg: Publications Office of the European Union.

Clarke, V., Braun, V., \& Hayfield, N. (2015). Thematic analysis. In J. Smith (Ed.). Qualitative psychology: A practical guide to research methods (3rd ed., pp. 222-248). London: Sage.

Desjardins, R. (2017). The Political Economy of Adult Learning Systems: Alternative Strategies, Policies and Coordination of Constraints. London: Bloomsbury.

European Commission. (2016). Proposals for a new European Consensus on Development. Our World, our Dignity, our Future. Strasburg. Retrieved from https://ec.europa. eu/europeaid/new-european-consensus-development-our-world-our-dignity-ourfuture_en

European Commission. (2017). Joint Working Group seminar on the integration of migrants. Meeting report. Retrieved from https://ec.europa.eu/education/sites/default/files/document-library-docs/2017-report-migrant-integration_en.pdf

European Commission. (2020). Communication from the Commission to the European Parliament, the Council, the European Economic and Social Committee and the Committee of the Regions on Achieving the European Education Area by 2025. Retrieved from https://eur-lex.europa.eu/legal-content/DA/TXT/?qid=151825266 $1475 \&$ uri=COM\%3A2020\%3A625\%3AFIN

European Commission. (2020). Digital Education Action Plan (2021-2027). Resetting education and training for the digital age. Retrieved from https://ec.europa.eu/education/education-in-the-eu/digital-education-action-plan_en

FENwick, T. (2001). Knowledge and the enterprising self: Workplace refugees navigating entrepreneurial discourse. Studies in the Education of Adults, 33(2), 127-134.

HaLACHEv, R. (2015). What role does adult education play in refugee crisis? Retrieved from https://epale.ec.europa.eu/en/blog/what-role-does-adult-education-play-refugeecrisis.

Haywood, M. (2007). Applying post-critical approaches to refugee-centered education. Retrieved from http://aut.researchgateway.ac.nz/bitstream/handle/10292/221/HaywardM.pdf?sequence $=2$

Heinemann, A. M. B. (2017). The making of 'good citizens': German courses for migrants and refugees. Studies in the Education of Adults, 49(2), 177-195. 
Käpplinger, B. (2018). Addressing refugees and non-refugees in adult education programs: A longitudinal analysis on shifting public concerns. European Journal for Research on the Education and Learning of Adults, 9(2), 161-177.

Knuden, L.V., Laplante- Le' vesque, A., Jones, L., Preminger, J.E., Nielsen, C., Lunner, T., Hickson, L., Naylor, G., \& Kramer, S.E. (2012). Conducting qualitative research in audiology: a tutorial. International Journal of Audiology, 51(2), 83-92.

Morrice, L., Shan, H., \& Sprung, A. (2017). Migration, adult education and learning, Studies in the Education of Adults, 49(2), 129-135.

OECD (2013). OECD Skills Outlook 2013: First results from the Survey of Adult Skills. Paris: Organization for Economic Cooperation and Development. Retrieved from http://skills.oecd.org/OECD_Skills_Outlook_2013.pdf

OHCHR (1993). Fact Sheet No20, Human Rights and Refugees. Retrieved from https:// www.refworld.org/docid/4794773f0.html

Panagiotopoulos, G., \& Karanikola, Z. (2017). Skills: a pathway to employability and prosperity. European Commission Policies. International Journal of Education, Learning and Development, 5(10), 92-101.

Panagiotopoulos, G., Pertesi, K., \& Karanikola, Z. (2018). Adult Education and International Organizations (UNESCO): Contemporary Policies and Strategies. International Journal of Learning and Development, Macrothink Institute, 8(3), 126-139.

Persson, H.C., Tornbom, K., Tornbom, M. (2017). Consequences and coping strategies six years after a after a subarachnoid hemorrhage - A qualitative study. PLoS ONE 12(8): e0181006.

Schuller, T., \& Watson, D. 2009.LEARNING through LifE: INQUiRY INTO THE FUTURE OF LIFELONG LEARNING. LEICESTER: NIACE.

SHAN, H. (2015). Distributed pedagogy of difference: Reimagining immigrant training and education. Canadian Journal for the Study of Adult Education, 27(3), 1-16.

UNESCO. GRALE II (2009). Global Report on Adult Learning and Education. Rethinking Literacy. Hamburg: UNESCO Institute for Lifelong Learning.

UNESCO (2010). Belém Framework for Action. Hamburg: UNESCO Institute for Lifelong Learning. Retrieved from http://unesdoc.unesco.org/images/0018/001877/ $187789 \mathrm{~m} . \mathrm{pdf}$

UNESCO (2015). Global Inventory of Regional and National Qualifications Frameworks, I, II. Hamburg: UNESCO Institute for Lifelong Learning. Retrieved from http:// unesdoc.unesco.org/ images/0023/002330/233043E.pdf

UNESCO (2016). Collection of Lifelong Learning Policies and Strategies. Hamburg: UNESCO Institute for Lifelong Learning. Retrieved from http://uil.unesco.org/ lifelong-learning/lifelong-learning-policy-analysis/collectionlifelonglearning-policies-and

UNESCO. GRALE III (2016). $3^{\text {rd }}$ Global Report on Adult Learning and Education. The Impact of Adult Learning and Education on Health and Well-Being; Employment and 
the Labour Market; and Social, Civic and Community Life. Hamburg: UNESCO Institute for Lifelong Learning.

UNESCO (2017). Working papers on Education Policy. Protecting the right to education for refugees. Education 2030. Hamburg: UNESCO Institute for Lifelong Learning.

UNESCO.GRALE 4 (2019). $4^{\text {th }}$ Global Report on Adult Learning and Education. Leave no one behind: Participation, Equity and Inclusion. Hamburg: UNESCO Institute for Lifelong Learning.

UNHCR (2016). Global Education Monitoring Report. No more excuses: Provide education to all forcibly displaced people. Policy Paper 26. Retrieved from https://en.unesco. org/gem-report/no-more-excuses

UNHCR (2021a). Europe Situations: Data and Trends. Arrivals and Displaced Populations Retrieved from https://data2.unhcr.org/en/documents/details/86420).

UNHCR (2021b). Arrivals to Europe from Libya. Retrieved from https://data2.unhcr.org/ en/documents/details/86602

UNHCR (2021c). Syria Refugee Crisis Explained. Retrieved from https://www.unrefugees.org/news/syria-refugee-crisis-explained/

United Nations General Assembly (2015). Human Development Report 2015: Work for Human Development. NY: United Nations Development Program. Retrieved from http://hdr.undp.org/sites/default/files/2015_human_development_report.pdf

Vaismoradi, M., \& Snelgrove, S. (2019). Theme in qualitative content analysis and thematic analysis. Forum Qualitative Social Research, 20(3), 1-14.

WATts, N., White, C., \& TRLIN, A. (2001).English language provision for adult immigrants andlor refugees from non-English speaking backgrounds in educational institutions and private training establishments in New Zealand. Palmerston North: Massey University.

World Education News and Reviews (2015). The importance of higher education for Syrian refugees. Retrieved from http://wenr.wes.org/2015/12/the-importance-ofhighereducation-for-syrian-refugees/ 
Zoe Karanikola ${ }^{3}$, Nektaria Palaiologou ${ }^{4}$

Helenski otvoreni univerzitet, Grčka

\section{Izbeglice i obrazovanje odraslih: tematska analiza najnovijih preporuka UNESKO-a}

Apstrakt: Savremena društva su primorana da se suoče sa kompleksnim izazovima proisteklim usled globalizma, ubrzane tehnološke evolucije, intenzivnih demografskih promena i socijalne ekskluzije. Ovi izazovi su sastavni deo globalnog mandata UNESKO-a, što je izloženo u „Okviru za akciju u domenu obrazovanja za 2030. godinu“, koji je usredsređen na implementaciju ciljeva održivog razvoja i ima veći uticaj na migracije i izbeglice. Globalni izveštaj UNESKO-a o učenju i obrazovanju odraslih ima ključnu ulogu u postizanju četvrtog cilja Agende, koji se tiče obrazovanja i celoživotnog obrazovanja. Aktuelno istraživanje je sprovedeno putem kvalitativne analize teksta UNESKO-a (GRALE 4, 2019) sa ciljem prepoznavanja osnovnih dimenzija obrazovanja odraslih izbeglica i načina na koje se ono može primeniti. Prilikom analize teksta, zapazili smo izvesne tematske mreže u vezi sa procentima učešća odraslih izbeglica, osmišljavanjem politika koje se prevashodno odlikuju ulaganjem u celoživotno učenje, prenosom dobrih praksi i njihovom evaluacijom.

Ključne reči: obrazovanje odraslih, učešće, izbeglice, politike, prakse.

\footnotetext{
${ }^{3}$ Dr Zoe Karanikola je tutor na Helenskom otvorenom univerzitetu, Grčka.

${ }^{4}$ Dr Nektaria Palaiologou je docentkinja na Helenskom otvorenom univerzitetu, Grčka.
} 